\title{
Dry matter production and light interception of crop surfaces. IV. Maximum herbage production as compared with predicted values
}

\author{
Th. Alberda
}

Institute for Biological and Chemical Research on Field Crops and Herbage, Wageningen, The Netherlands

Received 26 April, 1968

\begin{abstract}
Summary
When water and mineral nutrients are supplied to a grass sward in optimal amounts the yield of dry herbage per hectare per year can reach values of about 20 tons, with some variation as to the influence of variety and cutting scheme.

With the aid of data on the rate of dry matter production of a closed crop obtained earlier and with data on the rate of regrowth and on the length of the period between cutting and a closed crop surface presented in this paper, a table can be made with which one can predict with reasonable accuracy the total herbage production for a given cutting scheme.

Although less certain the mean chemical composition is also given for herbage yields between 3 and 4 tons ha $^{-1}$ at different times during the season.
\end{abstract}

\section{Introduction}

During six consecutive years experiments have been carried out in which the herbage growth rate of a completely closed green grass cover was compared with the theoretical total dry matter production values, calculated according to methods given by De Wit (1959 and 1965). From these data, however, no conclusions could be drawn as to the maximum herbage production per unit area a farmer could achieve, since no attention was paid to the regrowth after cutting.

From the above mentioned data it appeared that the rate of herbage production of a closed sward remains virtually constant for some period, after which rather suddenly a ceiling yield is reached (Alberda and Sibma, 1968). The production rate is mainly determined by temperature at the beginning and the end of the growing season but from May until the second half of September the light intensity is the rate determining factor. The rate of herbage production is highest in May and June and from then on drops slowly until the influence of temperature causes it to slow down more steeply. The ceiling yield is also highest at the beginning of the growth season and drops very steeply so that in August its value is only half of that in May.

Since both the growth rate and the ceiling yield in a given period were practically independent of (a) the weather conditions in a particular year, (b) the age and botanical composition of the sward as long as it consisted of 'good' grasses, and (c) the 
kind of soil, as long as water and minerals were provided in adequate amounts, it seemed possible to predict the total herbage production during a year with a given cutting scheme, provided that the production between the time of cutting and the moment at which a closed sward was reached again, was known. From existing data it could be concluded that a closed crop would be reached after cutting at a herbage weight of approximately $1500 \mathrm{~kg} \cdot \mathrm{ha}^{-1}$ dry matter. Data of Brougham (1956) indicate that the period necessary to reach this stage would be about four weeks. If, on this basis, a scheme could be drawn up which would fit with the actual production values the farmer could be provided with data enabling him to predict the herbage production of each cut when water and nutrients are available in optimal amounts.

\section{Methods}

With the known production rates for a closed sward and a period between cutting and a weight of $1500 \mathrm{~kg} \cdot \mathrm{ha}^{-1}$ of 3 weeks in the first half of the growing season and 4 weeks in the second, the course of herbage production during the season was constructed for two cutting régimes (Figure 1). It was assumed that the weight on 15 April was $1000 \mathrm{~kg} \cdot \mathrm{ha}^{-1}$. In one régime the grass was cut as soon as the ceiling yield was reached.

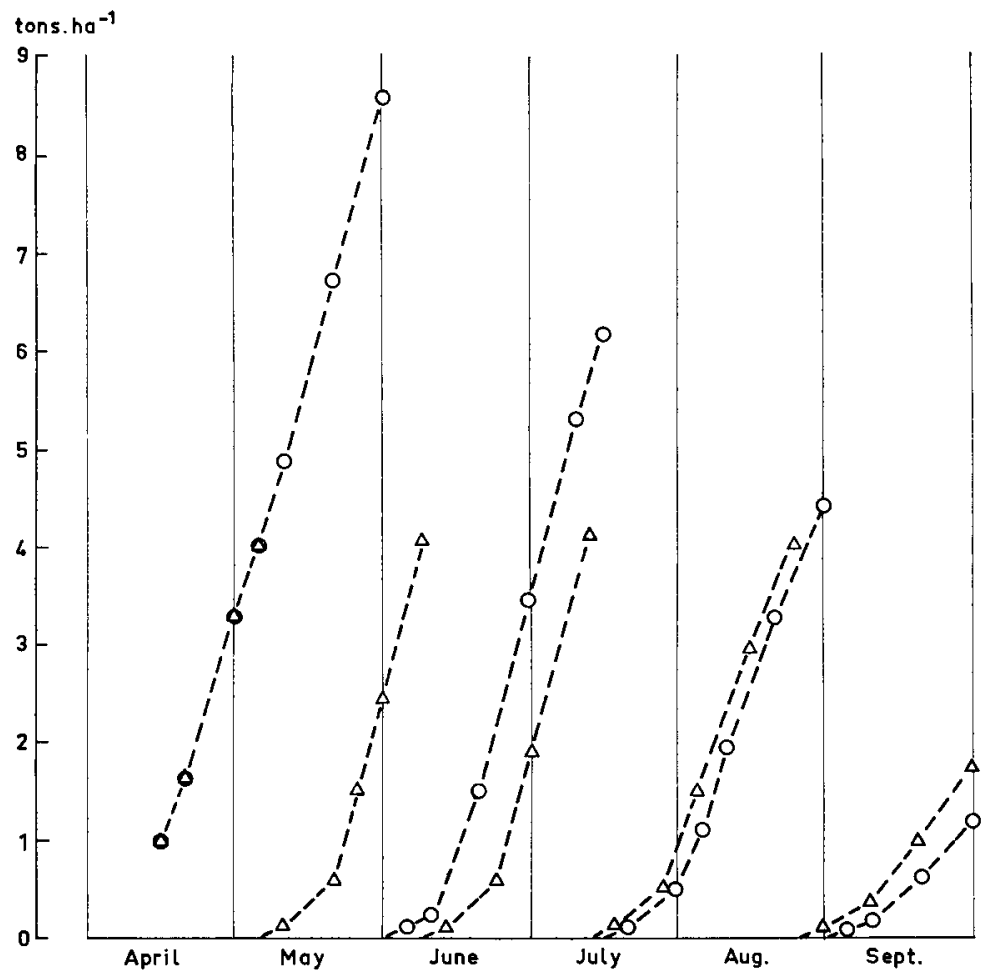

Fig. 1 Predicted course of dry herbage production for two cutting treatments 
This was thought to give the highest possible total herbage production at a value of 20.4 tons per hectare. The weight of the first cut is in this case expected to be over 8 tons per hectare. Since such grass will undoubtedly have a comparably low feeding value another cutting scheme was devised in which the grass was cut at a weight of 4 tons per hectare. In this way a total production of 17.8 tons of dry herbage was obtained.

To compare these predicted values with actual herbage production under the same cutting régimes a field in the polder East-Flevoland was sown in the autumn of 1966 with perennial ryegrass. Half of the field was sown with the early flowering variety Barenza 58-3 (hay-type), the other half with the late flowering variety Sceempter (pasture type). There followed a mild winter and in the spring of 1967 a dense sward was available for the experiments.

Both cutting schemes were carried out on both varieties. To determine the course of dry matter production strips from the swards were mown and the fresh weight and dry matter percentage determined. As soon as the weight limits were reached the whole area was cut.

During the first weeks after cutting an analysis of the rate of regrowth was not well possible, the amount of herbage present being too small. To obtain an idea of the rate of recovery of the green surface after cutting, two different methods were employed. The first consists of two light meters each connected to a Kipp galvanometer via a potentiometer. One meter contains one single selenium photocell and is used as a reference meter above the crop; the other has four small selenium cells mounted on a rod that is pushed underneath the crop. Before measuring, both light meters are placed close together above the crop and the galvanometer deflection is set at the same value by means of the potentiometers. Then the relative reduction in light intensity underneath the crop can be measured by taking a number of readings from each meter. After each ten measurements the meters are compared again and if they fail to give the same deflection the preceding readings are discarded. In the second method a small telescope is used that is mounted on an iron bar which is placed horizontally above the crop at a height of about $1.50 \mathrm{~m}$. The telescope can be moved along the bar and fixed in 100 different positions, $2 \mathrm{~cm}$ apart. At each position one can ascertain whether or not the crosswires in the telescope 'hit' a green leaf. In this way the percentage leaf cover can be measured from a vertical position as a mean of at least five separate measurements for one sward.

From each sample taken an analysis was carried out on the content of nitrate nitrogen, total nitrogen, water soluble carbohydrates, crude protein and ash. Occasionally an analysis on the main nutritional elements was carried out. As far as possible the nitrate content in the herbage was kept above 100 me per $\mathrm{kg}$ dry weight; criteria for the other elements were found in a paper by De Wit, Dijkshoorn and Noggle (1963). Whenever it was necessary to fertilize with nitrogen potassium was also added as potassium nitrate in a total $\mathrm{N} / \mathrm{K}$ ratio of 2 .

A sprinkler installation was used to supply water when necessary and to water the fertilizer in.

\section{Results}

When the grass was cut each time a weight of approximately four tons per hectare was reached (treatment $A$ ) five cuts could be made during the season, the first on 
Table 1 Yield and chemical composition of two perennial ryegrass varieties and two cutting treatments

\begin{tabular}{|c|c|c|c|c|c|c|c|c|c|c|}
\hline Type & $\begin{array}{l}\text { Cutting } \\
\text { scheme }\end{array}$ & $\begin{array}{c}\text { Sample } \\
n r .\end{array}$ & $\begin{array}{c}\text { Date } \\
\text { of } \\
\text { harvest }\end{array}$ & $\begin{array}{c}\text { Yield } \\
\mathrm{kg} . \mathrm{ha}-1\end{array}$ & $\begin{array}{c}\text { Dry } \\
\text { weight } \\
\%\end{array}$ & $\begin{array}{l}\text { Total } \\
\quad N\end{array}$ & $\begin{array}{c}\text { Sol. } \\
\text { sugars } \\
\%\end{array}$ & $\begin{array}{c}\text { Crude } \\
\text { fibre } \\
\%\end{array}$ & $\begin{array}{c}\text { Ash } \\
\%\end{array}$ & $\begin{array}{c}\text { Nitrate } \\
N \\
\%\end{array}$ \\
\hline & \multirow{6}{*}{ 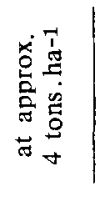 } & 1 & $9-5$ & 5570 & 14.3 & 3.10 & 16.1 & 22.8 & 12.9 & 0.029 \\
\hline & & 2 & $9-6$ & 5090 & 13.6 & 3.10 & 27.1 & 15.8 & 6.5 & 0.436 \\
\hline & & 3 & $21-7$ & 4940 & 12.8 & 2.43 & 4.1 & 31.7 & 15.3 & 0.054 \\
\hline & & 4 & $28-8$ & 3660 & 13.3 & 3.68 & 3.6 & 28.3 & 14.6 & 0.294 \\
\hline \multirow{2}{*}{ 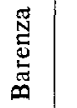 } & & & $3-10$ & 2990 & 15.8 & 3.74 & 4.6 & 24.9 & 16.9 & 0.396 \\
\hline & & & total yield & 22250 & & & & & & \\
\hline \multirow{5}{*}{ 悹 } & \multirow{5}{*}{ 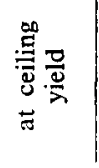 } & 6 & $25-5$ & 8400 & 10.5 & 2.59 & 6.7 & 29.0 & 13.3 & 0.163 \\
\hline & & 7 & $14-7$ & 6360 & 11.8 & 2.24 & 3.4 & 34.8 & 13.7 & 0.043 \\
\hline & & 8 & $28-8$ & 3790 & 14.2 & 3.73 & 3.4 & 27.5 & 14.4 & 0.314 \\
\hline & & 9 & $3-10$ & 2340 & 13.9 & 3.71 & 3.9 & 24.2 & 18.7 & 0.183 \\
\hline & & & total yield & 20890 & & & & & & \\
\hline \multirow{6}{*}{ 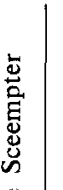 } & \multirow{6}{*}{ 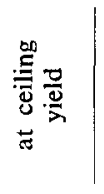 } & 10 & $12-5$ & 5350 & 16.8 & 2.91 & 9.9 & 24.8 & 15.9 & 0.034 \\
\hline & & 11 & $9-6$ & 4670 & 14.0 & 2.85 & 7.2 & 26.6 & 14.3 & 0.334 \\
\hline & & 12 & $21-7$ & 5040 & 13.4 & 2.67 & 4.7 & 32.6 & 13.2 & 0.093 \\
\hline & & 13 & $28-8$ & 3460 & 13.3 & 3.77 & 3.5 & 27.8 & 13.6 & 0.436 \\
\hline & & 14 & $3-10$ & 2750 & 14.8 & 3.62 & 3.9 & 24.6 & 20.4 & 0.251 \\
\hline & & & total yield & 21270 & & & & & & \\
\hline \multirow{5}{*}{ 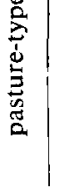 } & \multirow{5}{*}{ 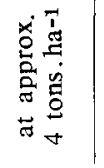 } & 15 & $30-5$ & 9040 & 11.6 & 2.53 & 6.6 & 31.6 & 12.6 & 0.124 \\
\hline & & 16 & $14-7$ & 5970 & 10.9 & 2.43 & 3.9 & 33.3 & 19.2 & 0.061 \\
\hline & & 17 & $28-8$ & 3230 & 13.9 & 3.94 & 3.4 & 27.8 & 12.6 & 0.422 \\
\hline & & 18 & $3-10$ & 2450 & 13.7 & 4.00 & 3.3 & 23.9 & 22.5 & 0.398 \\
\hline & & & total yield & 20690 & & & & & & \\
\hline \multicolumn{4}{|c|}{$\begin{array}{l}\text { mean of sample nrs } 1,2,3,4, \\
\quad 10,11,12,13\end{array}$} & 4720 & 13.9 & 3.07 & 9.5 & 26.3 & 13.3 & 0.215 \\
\hline \multicolumn{4}{|c|}{ mean of sample nrs $6,7,15,16$} & 7440 & 11.2 & 2.45 & 5.2 & 32.3 & 14.7 & 0.097 \\
\hline \multicolumn{4}{|c|}{ normal mean: } & & & & & & & \\
\hline \multirow{2}{*}{\multicolumn{4}{|c|}{$\begin{array}{l}\text { at } \pm 4.5 \text { tons. ha-1 } \\
\text { at } \pm 8 \text { tons. ha-1 }\end{array}$}} & 4530 & 12.9 & 3.50 & 7.7 & 27.7 & 9.8 & 0.334 \\
\hline & & & & 7900 & 14.3 & 2.80 & 8.4 & 31.1 & 9.7 & 0.235 \\
\hline
\end{tabular}

May 9th and the last on October 3rd. When the cuts were made at ceiling yield (treatment B) there were four, the first on May 25th, the last on October 3rd. As the grass grew very quickly during May and June the cuts of treatment A were higher than was anticipated. The dry weight of each cut, the chemical analysis, the starch equivalent value and the total herbage dry weight over the season are given in Table 1 for both ryegrass varieties and both treatments. For treatment B there was no distinct difference between the yield that was expected and those that were obtained for both varieties. Contrary to the expectation, however, the yield of treatment $\mathbf{A}$ was higher than that of treatment $\mathbf{B}$ and 4 tons per hectare higher than the expected value for the hay-type and 3 tons for the pasture type.

The course of dry herbage production can be seen in Figure 2, together with the expected growth curves. For the B-treatments there was little difference between the actual and expected production during the first two growth periods. For the third 

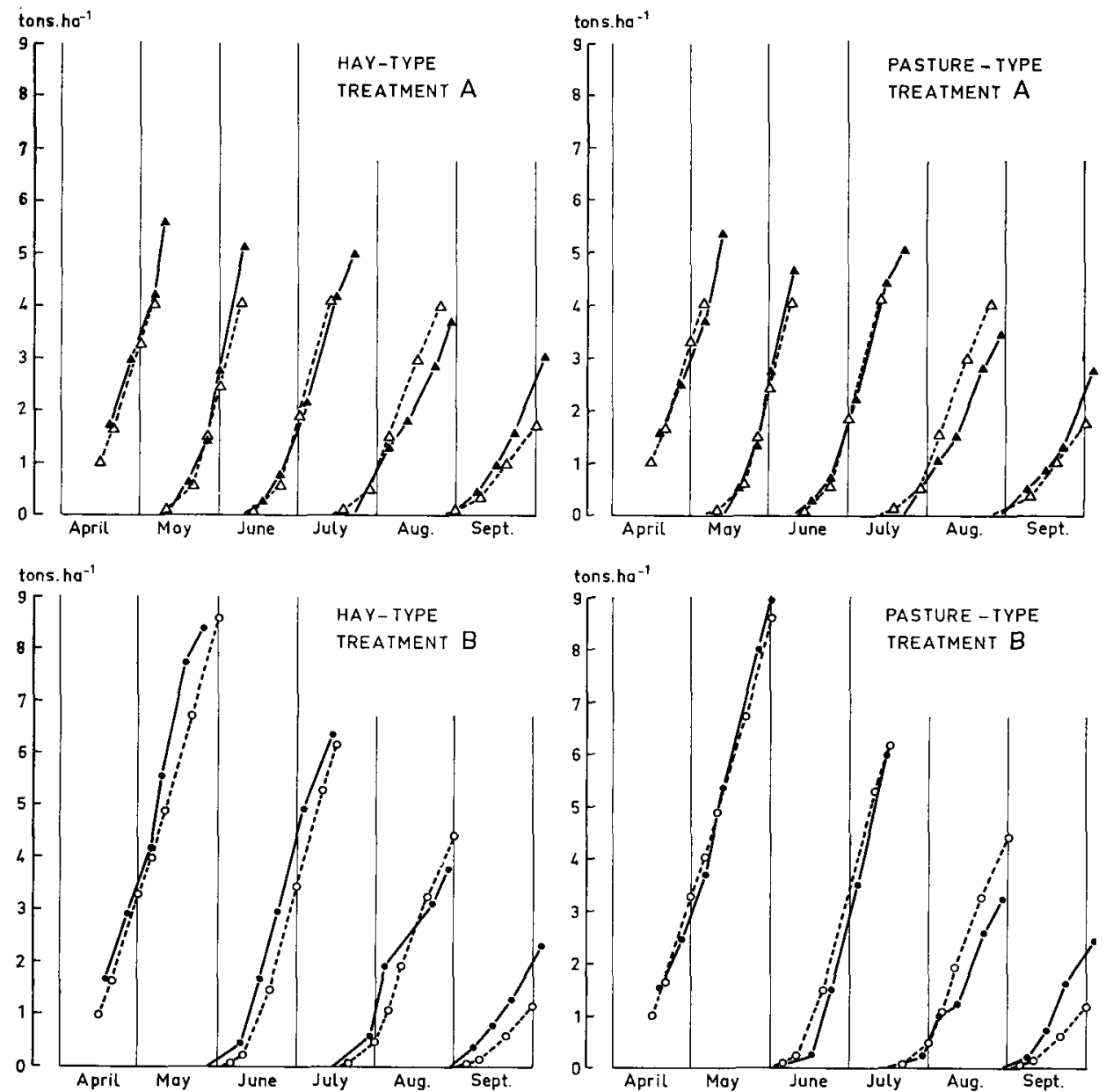

Fig. 2 Actual and predicted course of dry herbage production for two ryegrass varieties and two cutting treatments. Open symbols predicted values, closed symbols actual values

period the expected growth was somewhat better than the actual, especially with the pasture-type, but during the fourth period the difference was in the opposite direction, resulting in only slight differences in the total amount of dry herbage. For the A treatments there was also little difference between the actual and predicted growth rates, but as the weights at the end of each period of growth were higher than was expected total dry weight over the season was higher and the fourth growing period commenced later than planned. This brought about a lower final weight than was expected. Growth rates over this period, however, corresponded well with the calculated values. During the last growth period the actual growth rate was higher than the predicted one. Together these differences resulted in the observed weight difference over the whole season. 

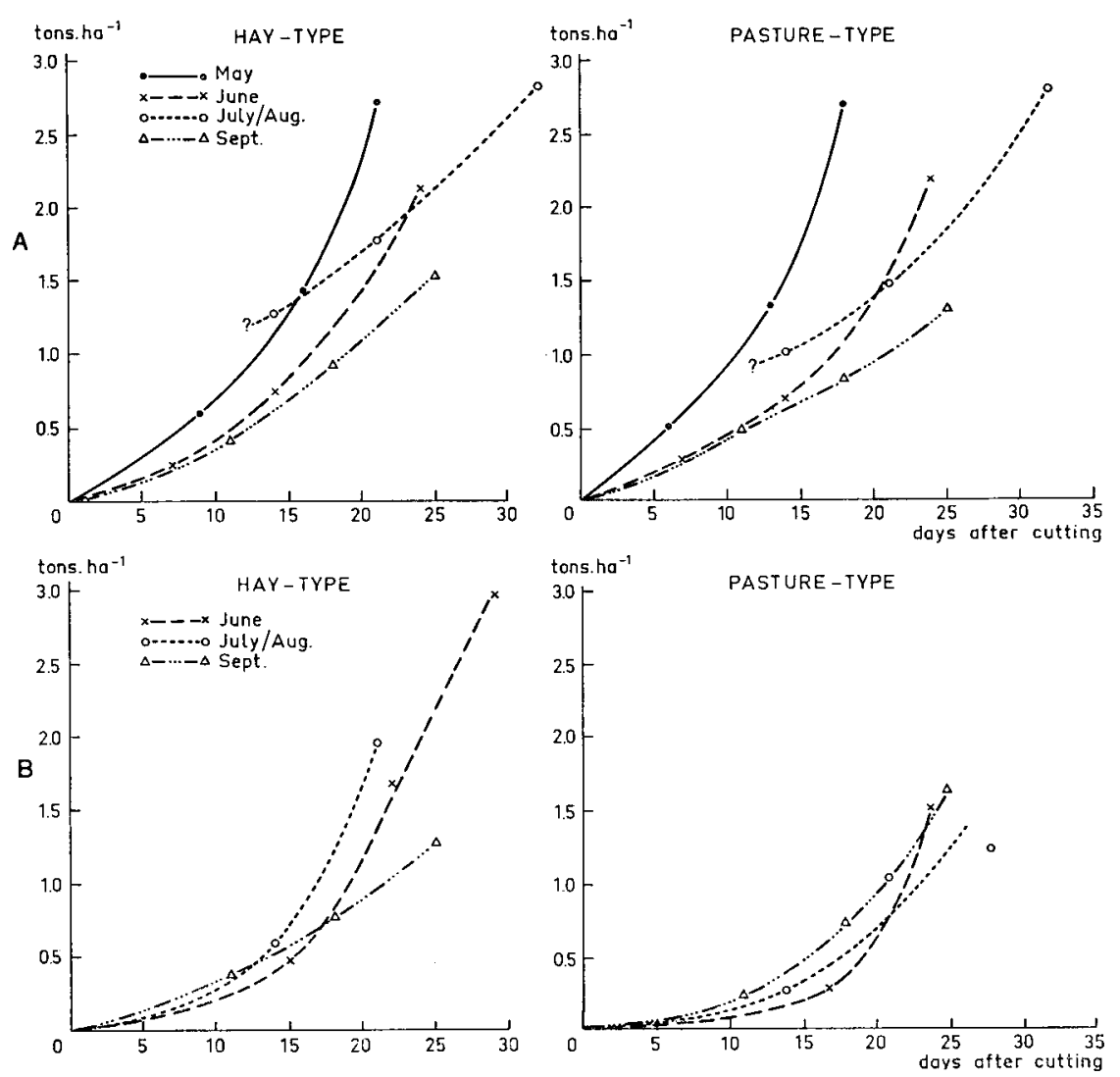

Fig. 3 Rate of regrowth after cutting for two ryegrass varieties and two cutting treatments

The first part of the regrowth curves for the $\mathbf{A}$ treatment is given in Figure $3 \mathrm{a}$ and that for the B-treatment in Figure $3 b$ in more detail. All weight data can be extrapolated to zero at the time of cutting except the July-August regrowth of the Atreatment, where the first weight measurement was unfortunately taken rather later than usual. The course of increase in weight in the other regrowth periods was rather regular. In the A-treatments the growth rate diminished as the season proceeded, the first regrowth being much faster than the other ones especially in the case of the pasture type. With the B-treatments it was more complicated. Apparently the slower regrowth after a heavy cut was more important than the decrease with the season, for the rate of regrowth during the first weeks after cutting increased from the first to the last growth period. As the amount of green tissue increased, however, the seasonal influence became more important, causing a rapid increase in the regrowth rate after the first point on the curve. Once again the July-August regrowth curve was irregular in that it showed the same picture with the hay-type but not with the pasture type.

Figure 4 also gives a picture of the regrowth after cutting in treatment $A$. In the upper half the percentage of leaf hits is plotted against the time after cutting. After 

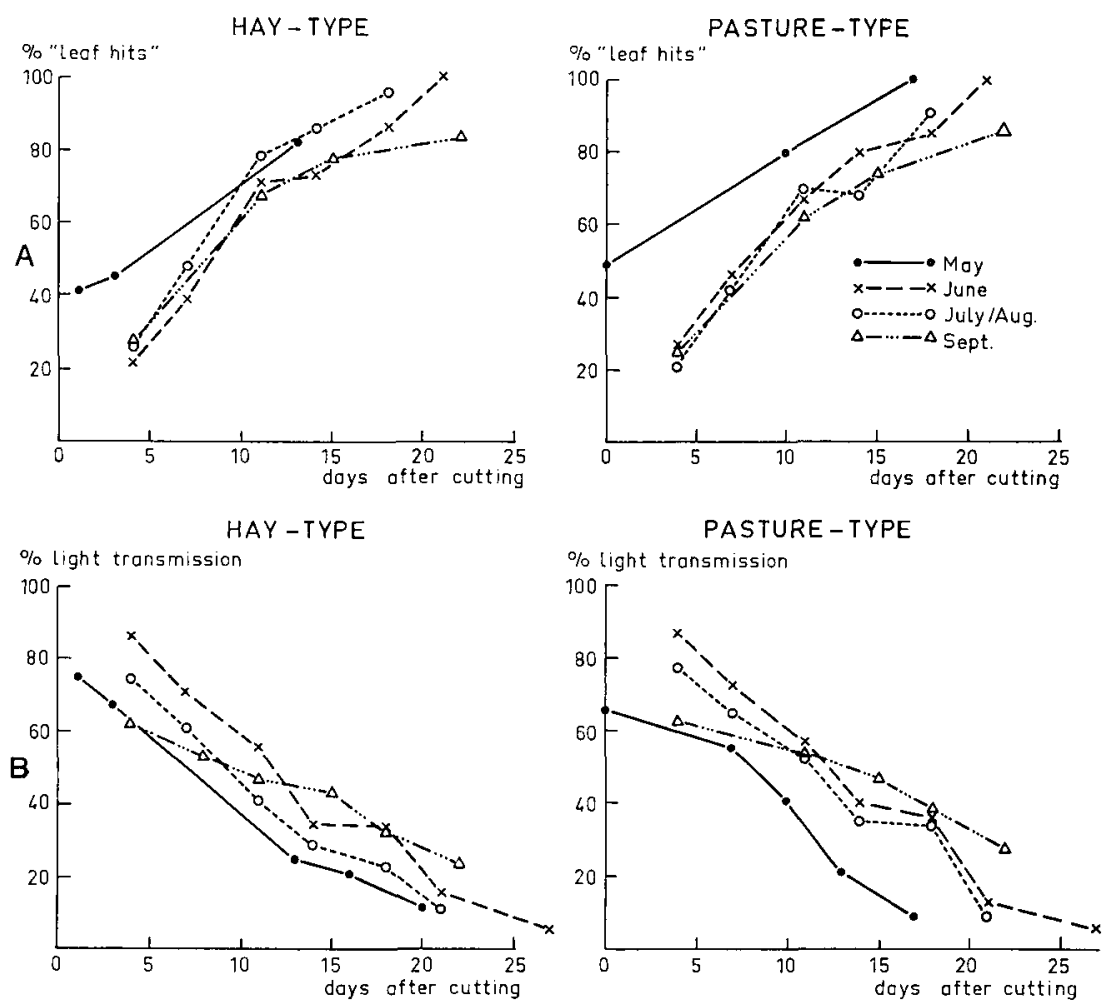

Fig. 4 The course of leaf development and light transmission during the first weeks after cutting (4 tons cutting scheme)

the first cut there was a considerable amount of green tissue remaining in the sward, especially in the pasture type. For the other three cuts the lines can be extrapolated to zero indicating practically no green material present immediately after cutting. For most regrowth periods a figure of 100 per cent leaf hits was reached at about three weeks after cutting: the first regrowth period of the pasture type was, however, shorter and both September periods were longer. The July-August period, which showed a rather low rate of regrowth in the preceding figure in terms of dry weight, followed a more normal course here.

Figure $4 \mathrm{~b}$ shows the light transmission values for the same plots as above. In general the trend is the same. It must be noted, however, that the curves are not corrected for the fact that the galvanometer deflection is not linear with the receiving light intensity. At three weeks after cutting the light intensity below the sward was not yet below 10 per cent of that above the sward, except perhaps for the first cut of the pasture type. Nevertheless it can be seen from Figure 2 that the rate of regrowth in all cases had already reached the linear stage.

In Figure 5 the percentage leaf hits as well as the relative light transmission is plotted against herbage weight. At a weight of $1500 \mathrm{~kg} \cdot \mathrm{ha}^{-1}$ no more soil or dead plant material was visible when seen vertically from above. However, at this weight the light transmission was still 20 per cent. This is plausible of course, since the light 


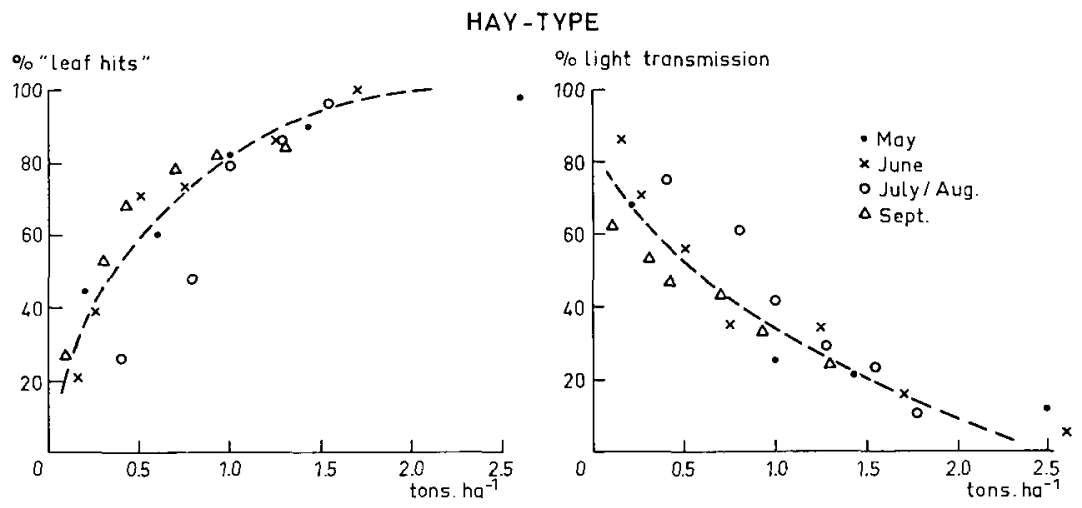

Fig. 5 The relation between leaf development or light transmission and herbage growth (hay-type, 4 tons cutting treatment)

does not only penetrate from a vertical direction. But nevertheless it seems that the criterium taken for the beginning of a closed crop stage, viz. $1500 \mathrm{~kg}$ per hectare is all right and also that this stage can be reached in about three weeks after cutting. Apparently the last percentages reduction in light transmission do not influence the rate of dry matter production to an appreciable degree.

All these light interception data refer to the A-treatment. For the B-treatment the data from the first and second cut are compared with those of the second and third cut of the A-treatment in Figure 6, since these are comparable in time of the year. Especially with the pasture type there was a distinctly lower percentage of leaf hits for the B-treatment during the first weeks after cutting. This difference is also distinctly visible in the rate of regrowth of these cuts in both treatments (Figure 3).

The data on the chemical composition are very irregular (Table 1). During the earlier years there always appeared to be a distinct relationship between the water soluble sugar content and the nitrate nitrogen content. When the latter was kept high, i.e. above
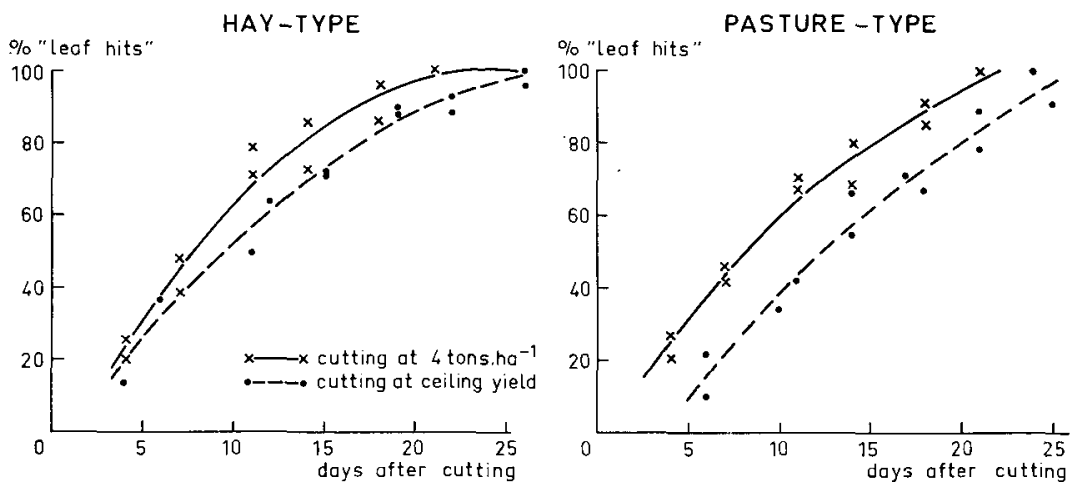

Fig. 6 The difference in leaf development between the two cutting schemes for two contemporary regrowth periods 
100 me per $\mathrm{kg}$ dry herbage, the sugar content was usually between 6 and 10 per cent of the dry weight. When the nitrate content was distinctly below 100 me per $\mathrm{kg}$ the sugar content rose immediately above 10 per cent. During 1967, however, many strange combinations of nitrate and sugar content occurred. This is already evident in the first two harvests given in Table 1. At the first harvest the nitrate content was far below $100 \mathrm{me}$ per $\mathrm{kg}$ dry herbage $(=0.14$ per cent of the dry weight $)$ and the sugar content was above 10 per cent, in accordance with what has been said before. At the second harvest, however, the nitrate content was far above the men. tioned value, but the sugar content was even higher that at the preceding harvest. On the other hand the sample nrs 16 and 17 show also very great differences in nitrate content, but both have a sugar content below 4 per cent, a value often met with during 1967, but hardly ever in earlier experiments.

Other abnormal values are the very high figures for the ash content in several samples; the nrs 14 and 18 have even percentages higher than 20 . In contrast, sample 2 is very low with an ash content of 6.5 per cent.

When the mean values of herbage weights of about 4.5 tons per hectare and of about 7.5 tons per hectare are compared with those of the same weights in earlier years the differences are not so great (last four rows of Table 1). In the 1967 samples the ash content was higher and the total nitrogen content was lower than the mean figures of the preceding years, the other differences being small or not always in the same direction.

\section{Discussion}

When the soil is supplied with the optimal amount of water and nutrients the dry herbage production per hectare per year can reach values of about 20 tons, which is at least double the value that is usually obtained in the Netherlands and elsewhere in Western Europe. For many crops 1967 has been a year with exceptionally high yields but if one takes this into account the predicted value of about 18 tons, based on data of normal years, seems to be well within possible bounds. It must be stated, however, that these yields have been obtained on leys, sown during the previous year, and that no data are yet available from the same treatment over a prolonged number of years.

To obtain the high production values it is also a prerequisite that the cut grass is immediately transported from the field, so that no natural hay-making is possible. The grass must either be fed directly to the animal or conserved in the form of silage or artificially dried product.

With normal grassland management a midsummer depression in herbage production is usually observed ('t Hart, 1948). It has already been shown that such a depression is not found in the rate of dry matter production of a closed sward and that the cause, therefore, could only be a slower rate of regrowth during the end of July and the beginning of August. Unfortunately the regrowth data obtained in this experiment do not allow any straight-forward conclusion to this problem for it is the July-August regrowth period that gives irregular results (Figure 3). If one looks at the percentage leaf hits or light interception, the rate of recovery of a green leaf canopy during the July-August period is certainly no lower than during the preceding or the following regrowth period (Figure 4). At any rate there are no clear 


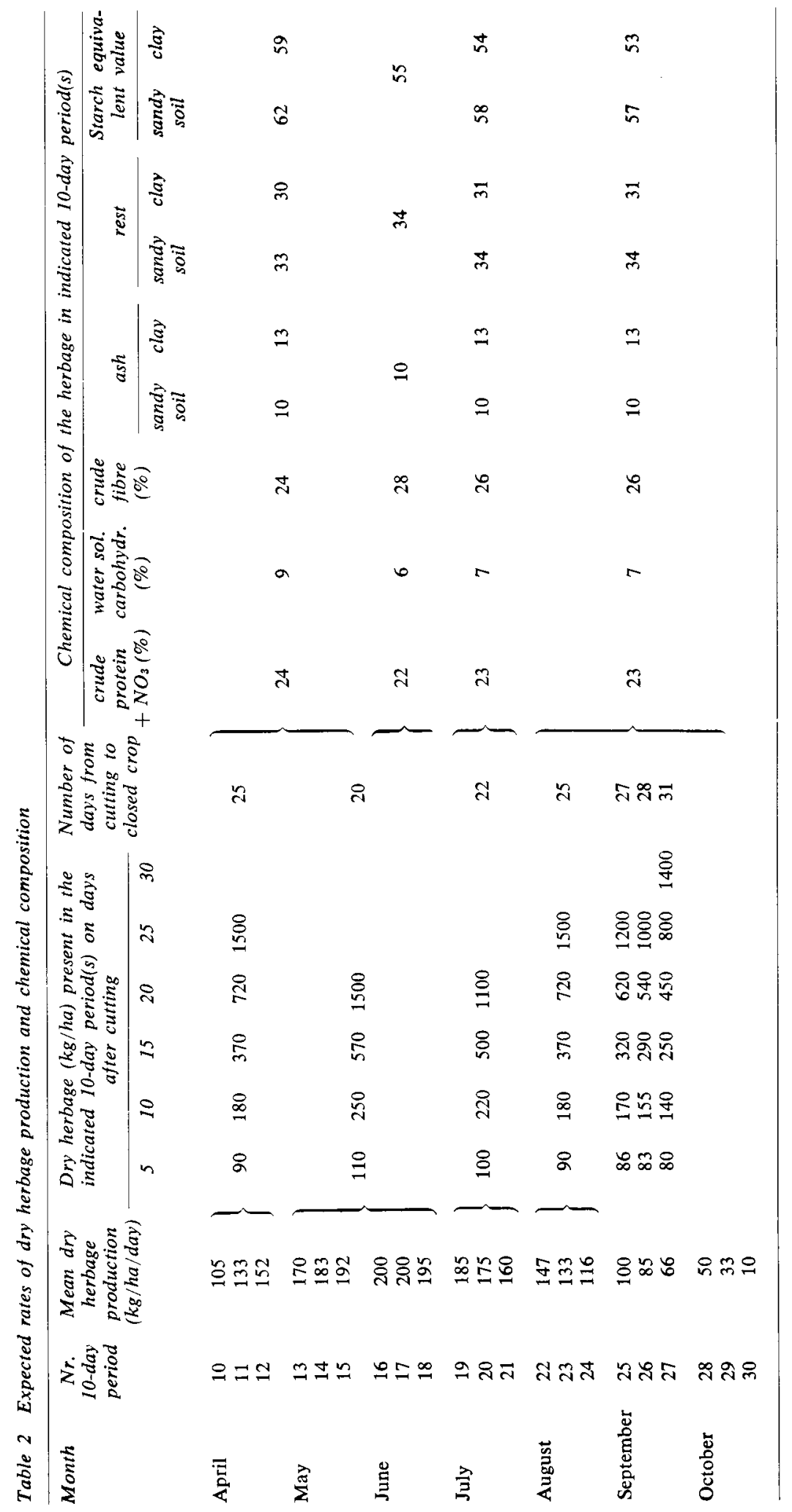


indications that with the treatment given in this experiment, a midsummer depression is present.

It is clear from Figure 3 that a heavy cut in the subsequent period has an adverse effect in the rate of regrowth as compared with a more lenient cut. This is especially evident in the case of the pasture type, where both the June and the JulyAugust curve differ considerably between the two treatments. There is still some difference between the two September curves although there was hardly any difference in the harvest weight at August 28th. Apparently there is still some after effect of the foregoing treatment, as can also be concluded from the weight of the last harvest (Table 1).

For treatment $\mathrm{A}$ the total yield of the hay-type was about $1000 \mathrm{~kg}$ per hectare higher than that of the pasture type; for treatment $\mathrm{B}$ there was no difference.

With the restrictions on the continuous production, made in the beginning, it is now possible to provide a reasonable estimate of the total dry matter production for a given cutting regime, provided that the soil factors are optimal. On the basis of the available evidence on growth, regrowth and chemical composition a table has been constructed (Table 2) in which the growth rate or the regrowth rate can be read for each ten day period throughout the growing season, enabling an estimate of yield under any given cutting regime to be made. Where it is intended to harvest at yields of between 3 and 4 tons dry herbage per ha, use may be made of the chemical composition and the starch equivalent values which have been tabulated. With the relatively large differences in ash content between the grass grown in the sandy soil near Wageningen and that on the clay soil of the East Flevoland polder two different values are given which, of course have their influence on the starch equivalent values. Whether these differences are usually observed between sandy soils and clay soils is not known.

It must be stated that a closed crop of $1000 \mathrm{~kg}$ dry herbage present at April 15th has formed the starting point. During this period, however, the temperature is still an important factor in determining the growth rate. The same can be said of the end of the growth season ,e.g. after September 15th. During these two periods deviations from the scheme may occur. They will usually not influence the total amount of dry herbage to an appreceable extent.

The total amount of nitrogen applied was about $600 \mathrm{~kg}$ per hectare. It follows from Table 1 that the amount of nitrogen recovered with the herbage is for treatment $\mathrm{A}$ about $715 \mathrm{~kg} \cdot \mathrm{ha}^{-1}$ for the hay-type and $675 \mathrm{~kg} \cdot \mathrm{ha}^{-1}$ for the pasture type. This means that the soil has released about $100 \mathrm{~kg}$ nitrogen per hectare to the herbage and also an unknown amount to the roots and stubble. Since an unlimited supply of nitrogen has the tendency to increase the water content and to decrease the soluble carbohydrate content the next step will be to try to keep the dry matter production at the maximum level with the minimum amount of nitrogen for several consecutive years on the same area.

\section{Acknowledgements}

Thanks are due to the Rijksdienst IJsselmeerpolders for the given facilities, to the Landbouwkundig Bureau der Nederlandse Stikstofmeststoffenindustrie for financial support, to members of the I.B.S. for their help with the experiment and the chemical analyses and to miss Alison Davies, Aberystwyth for overseeing the text. 


\section{Keferences}

Alberda, Th. and Sibma, L., 1968. Dry matter production and light interception of crop surfaces. III. Actual herbage production in different years as compared with potential values. J. Brit. Grassl. Soc. (In press.)

Brougham, R. W., 1956. Effect of intensity of defoliation on regrowth of pasture. Austr. J. Agric. Res., 7 : $377-387$.

Hart, M. L. 't, 1948. De seizoenschommelingen van de grasgroei in Nederland. Maandbl. Landb. voorl., 5 : 137-148.

Wit, C. T. de, 1959. Potential photosynthesis of crop surfaces. Neth. J. Agric. Sci, 7: $141-149$.

Wit, C. T. de, 1965. Photosynthesis of leaf canopies. Agric. Res. Rep. 663. Pudoc, Wageningen. $60 \mathrm{pp}$.

Wit, C. T. de, Dijkshoorn, W. and Noggle, J. C., 1963, Ionic balance and growth of plants. Versl. Landbk. Onderz. 69.15. Pudoc, Wageningen. 68 pp. 